University of South Carolina

Scholar Commons

\title{
Seaweed and Soy: Companion Foods in Asian Cuisine and Their Effects on Thyroid Function in American Women
}

Jane Teas

University of South Carolina - Columbia

Lewis E. Braverman

Mindy S. Kurzer

Sam Pino

Thomas G. Hurley

See next page for additional authors

Follow this and additional works at: https://scholarcommons.sc.edu/

sph_epidemiology_biostatistics_facpub

Part of the Public Health Commons

\section{Publication Info \\ Published in Journal of Medicinal Food, Volume 10, Issue 1, 2007, pages 90-100. \\ Teas, J., Braverman, L.E., Kurzer, M.S., Pino, S., Hurley, T.G., \& Hébert, J.R. (2007). Seaweed and Soy: Companion Foods in Asian Cuisine and Their Effects on Thyroid Function in American Women. Journal of Medicinal Food, 10(1), 90-100. DOI: 10.1089/jmf.2005.056 \\ This is a copy of an article published in the Journal of Medicinal Food @ 2007 Mary Ann Liebert, Inc. and Korean Society of Food Science and Nutrition; Journal of Medicinal Food is available online at: http://online.liebertpub.com.}

This Article is brought to you by the Epidemiology and Biostatistics at Scholar Commons. It has been accepted for inclusion in Faculty Publications by an authorized administrator of Scholar Commons. For more information, please contact digres@mailbox.sc.edu. 


\section{Author(s)}

Jane Teas, Lewis E. Braverman, Mindy S. Kurzer, Sam Pino, Thomas G. Hurley, and James R. Hébert 


\title{
Seaweed and Soy: Companion Foods in Asian Cuisine and Their Effects on Thyroid Function in American Women
}

\author{
Jane Teas, ${ }^{1,2}$ Lewis E. Braverman, ${ }^{3}$ Mindy S. Kurzer, ${ }^{4}$ Sam Pino, ${ }^{3}$ Thomas G. Hurley, ${ }^{2}$ \\ and James R. Hebert $2,5,6$ \\ ${ }^{5}$ Department of Biostatistics and Epidemiology, Arnold School of Public Health, ${ }^{1}$ University of South \\ Carolina; ${ }^{2}$ South Carolina Cancer Center, Columbia; ${ }^{6}$ Hollings Cancer Center, Charleston, South Carolina; \\ ${ }^{3}$ Section of Endocrinology, Diabetes and Nutrition, Department of Medicine, Boston University School of \\ Medicine, Boston, Massachusetts; and ${ }^{4}$ Department of Food Science and Nutrition, University of Minnesota, \\ St. Paul, Minnesota
}

\begin{abstract}
Seaweeds and soy are two commonly eaten foods in Asia. Both have been reported to affect thyroid function, seaweed because of its iodine content and soy because of its goitrogenic effect. Twenty-five healthy postmenopausal women (mean age 58 years) completed a double-blinded randomized crossover study. Ten capsules (5 g/day) of placebo or seaweed (Alaria esculenta), providing $475 \mu \mathrm{g}$ of iodine/day, were consumed daily for 7 weeks. A powdered soy protein isolate (Solae Co., St. Louis, MO), providing $2 \mathrm{mg}$ of isoflavones $/ \mathrm{kg}$ of body weight, was given daily during the last week of each treatment arm. On average, this provided $141.3 \mathrm{mg}$ of isoflavones/day and $67.5 \mathrm{~g}$ of protein/day. Blood samples and 48-hour urine samples were collected before and after each intervention period, and urinary I/C ( $\mu \mathrm{g}$ of iodine/g of creatinine) and serum thyroxine, free thyroxine index, total triiodothyronine, and thyroid stimulating hormone (TSH) were measured. Seaweed ingestion increased I/C concentrations $(P<.0001)$ and serum TSH $(P<.0001)(1.69 \pm 0.22$ vs. $2.19 \pm 0.22 \mu \mathrm{U} / \mathrm{mL}, \mathrm{mean} \pm$ $\mathrm{SE})$. Soy supplementation did not affect thyroid end points. Seven weeks of $5 \mathrm{~g}$ /day seaweed supplementation was associated with a small but statistically significant increase in TSH. Soy protein isolate supplementation was not associated with changes in serum thyroid hormone concentrations.
\end{abstract}

KEY WORDS: • breast cancer • chemoprevention • diet • postmenopausal women • seaweed • soy • thyroid stimulating hormone

\section{INTRODUCTION}

$\mathbf{S}^{\mathrm{t}}$ EAWEEDS ARE PART of many indigenous cuisines around the world, and have been incorporated into some healing therapies, including traditional Chinese medicine, Ayurveda, and modern macrobiotics, as well as many folk medicines. On a population level, those people for whom seaweed is a regular part of their diet, most notably in Japan, have dramatically lower breast cancer and prostate cancer rates. ${ }^{1-3}$ Epidemiologic studies done in the 1980s, before Westernized diets were common, found that Japanese women had one-third the rate of premenopausal breast cancer and one-ninth the rate of postmenopausal breast cancer. ${ }^{4}$ In addition, when a Japanese woman developed breast cancer, she was more likely to survive at least 5 years longer than women with breast cancer in the United States. ${ }^{5,6}$ The histologic type of breast cancer also varies by country, with

Manuscript received 20 October 2005. Revision accepted 30 December 2005.

Address reprint requests to: Jane Teas, Ph.D., South Carolina Cancer Center, 2221 Devine Street, Room 230, Columbia, SC 29208,E-mail: jane.teas@palmettohealth.org
Japanese women having greater humoral immune responses to the tumors as suggested by the greater degree of lymphocytic invasion of their breast tumors. ${ }^{5}$

No previous intervention studies have combined seaweed and soy, but epidemiologic evidence suggests that this combination could be anticarcinogenic. Consumption of miso soup has been associated with reduced breast cancer rates. ${ }^{7-9}$ Miso soup is usually a combination of soy (miso, tofu cubes) and seaweed (as a stock flavoring and as garnish), and sometimes vegetables.

Seaweed is not necessarily a safe food to consume. We have reported elsewhere that commonly consumed seaweeds have a wide range of iodine concentrations, i.e., between 16 $\mu \mathrm{g} / \mathrm{g}$ and $8,000 \mu \mathrm{g} / \mathrm{g},{ }^{10}$ making iodine an important doselimiting factor in seaweed consumption, particularly for people not accustomed to eating seaweed. ${ }^{11}$ The lowest-observed-adverse-effect level, based on increases in serum thyroid stimulating hormone (TSH) in thyroid function challenge tests, is $1,700 \mu \mathrm{g} / \mathrm{day}$ (U.S. and Canadian RDI Committee). ${ }^{12}$ However, habituation to high iodine-containing seaweeds appears to be common in Asia, particularly Japan, Korea, and coastal China, where seaweeds are frequently 
eaten and appear to be well tolerated by millions of people. The average seaweed intake in Japan is approximately 4-7 $\mathrm{g} / \mathrm{day},{ }^{13-15}$ with some estimates as high as $10 \mathrm{~g}$ per person per day. ${ }^{16}$ It is difficult to quantify the actual amount of seaweed consumed as it is often added as flavoring to noodles, soups, and garnishes and may be served as a snack, salad, or side dish. Based on dietary intake surveys, the average daily iodine intake in these regions is between 500 and 1,000 $\mu \mathrm{g} /$ day (ranging from 200 to $20,000 \mu \mathrm{g} /$ day), with most of the dietary iodine coming from seaweed consumption. ${ }^{16}$ For this study, we chose a low-iodine-containing seaweed (Alaria esculenta) to approximate the Japanese average seaweed intake, rather than the approximate iodine intake.

Soyfoods have been suggested as possible human goitrogens. ${ }^{17}$ The dose of soy protein in our study (average 67.5 g/day) was based on early estimates of average total soy intake in Japan. ${ }^{18}$ More recent dietary studies indicated that the soy protein intake in Japan is actually lower (10 g/day).

The present study determined whether iodine in seaweed was bioavailable and would affect thyroid function, whether a short-term soy protein isolate supplementation would affect thyroid function, and whether consumption of these two foods together would have any discernible effect on thyroid function that might be clinically important. Individual contrasts were created to test three hypotheses: (1) was seaweed different from placebo (seaweed main effect), (2) was soy different from placebo (soy main effect), and (3) was there an effect from combining seaweed and soy that was different from the additive effects of seaweed plus soy (seaweed soy interaction)? Since the greatest difference between U.S. and Japanese breast cancer rates begins at about age 45 years, ${ }^{19}$ we studied only postmenopausal women.

\section{SUBJECTS AND METHODS}

\section{Study population}

The University of Massachusetts Medical School Institutional Review Board approved the study. Consent forms were reviewed verbally, and all participants gave written informed consent.

Participants were a group of Caucasian American women living in central Massachusetts. We specifically recruited healthy postmenopausal women who had been treated for early breast cancer and women who had never had breast cancer. Women were recruited by word of mouth, by physicians, and through responses to an article in the newspaper. Our inclusion criteria included being postmenopausal (no bleeding for at least 1 year), intact ovaries at the time of menopause, no history of cancer (other than early breast cancer), no thyroid dysfunction or treatment within the previous 5 years, negative thyroid peroxidase antibodies excluding Hashimoto's thyroiditis, no hormone replacement therapy within the previous 3 years, no ulcer medications or lithium-based medications, no gastrointestinal disorders such as Crohn's disease or irritable bowel syndrome, no allergies to seaweed, soy, shellfish, or iodine, no treatment with oral antibiotics, iodine-containing medications, or corticosteroids within the previous 3 months, no diabetes, and no high blood pressure medications. In addition, only nonvegetarian women who consumed soy products fewer than two times per week were eligible. Women agreed to avoid eating soy foods during the study, including soybeans and soy products, as well as sprouts, beans, peas, and lentils, and to restrict alcoholic intake to one or fewer drinks per week. Although vitamin and supplement use was allowed, women were asked to refrain from changing dosage or usage during the study. Use of black cohosh, Dong Quai herbal supplements, or yam cream was an additional reason for ineligibility.

Forty-eight postmenopausal women were recruited. Based on screening blood samples, we excluded 15 additional women, two for abnormal serum TSH values (either $<0.4$ or $>4.5 \mu \mathrm{U} / \mathrm{mL}$ TSH), three for elevated thyroid peroxidase antibodies, three for current or recent thyroid medications, and seven for lack of interest. Thus, 33 women were enrolled in the study and provided baseline data. Subsequently, four women dropped out during the course of the study because of a lack of interest (one), naturopath advice (one), or allergic reaction (two). Of the two who developed allergic reactions to seaweed, one had red itchy eyes, and the other experienced re-activated esophageal reflux. Both conditions resolved spontaneously following cessation of seaweed intake. At the end of the study, two women were excluded because one woman began menstruating again, while the other failed to follow study protocol.

Following publication of studies during the trial on the effects of tamoxifen/roloxifen on thyroid function, ${ }^{20-22}$ we excluded the three women who used tamoxifen during the entire study, and the one woman who started taking tamoxifen late in the trial had her last three observations omitted. Her earlier measures were included in the analysis. This left a final study sample of 25 women among whom 10 had a history of early (Stage I or II) breast cancer but were disease free at the time of the study and 15 women who had never been diagnosed with breast cancer.

\section{Study design}

The study utilized a randomized, placebo-controlled crossover design. Women were randomized to either 6 weeks of $5 \mathrm{~g}$ /day seaweed powder (10 capsules) each evening with the last meal of the day or 6 weeks of $5 \mathrm{~g} /$ day maltodextrose in 10 identical gelatin capsules. For 1 additional week, women received either seaweed capsules or placebo capsules and the high isoflavone powder. To minimize possible effects of season, all women began the study the same week in late October. Samples were collected a total of seven times (blood samples and 48-hour urine collections) throughout the study. A 3-week washout period separated the two arms of the study, and a final 3-week washout period followed the end of the last supplements (Fig. 1).

Randomization was done using a computer-generated random number table. In addition, to assure blinded laboratory 


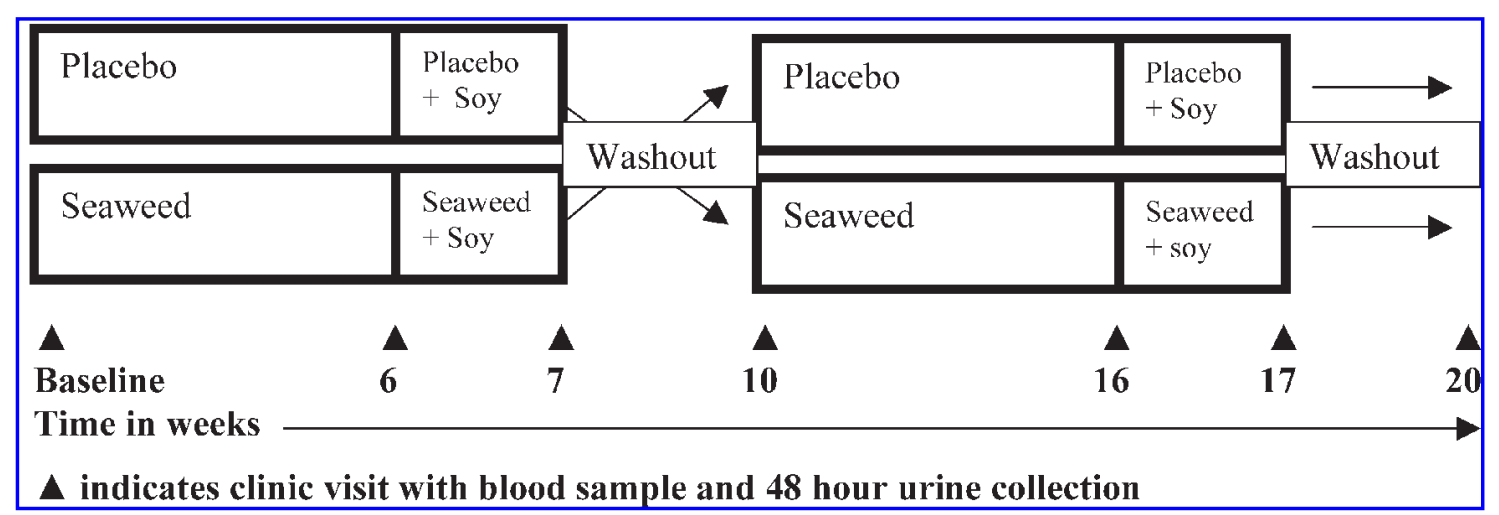

FIG. 1. Study design.

analysis, each patient at each clinic visit was assigned a unique ID number.

\section{Seaweed}

In order to ensure safe iodine exposure, seaweed samples were collected from seaweed harvesters and health food stores for a preliminary survey of iodine analysis (Fig. 2). For this study, we chose A. esculenta, also known as American wakame, a low-iodine (95 $\mu \mathrm{g} / \mathrm{g})$-containing seaweed. The A. esculenta was harvested at an extremely low tide from the subtidal rocks of the Sally Islands, lo- cated near Stuben, ME. The blades of Alaria were cut by hand, placed in plastic baskets, and transported from the islands to the shore in a separate boat made especially for hauling seaweed, which was towed behind a larger boat. No gasoline or other potentially toxic substances were present in the seaweed barge. Within 1 hour of harvesting, the seaweed fronds were hung on untreated wooden racks to sun-dry. After about 10 hours in the sun, the fronds were gathered in bundles, placed in plastic bags, and stored at ambient room temperature in a dark room until shipping, which was done within 2 months of harvest.

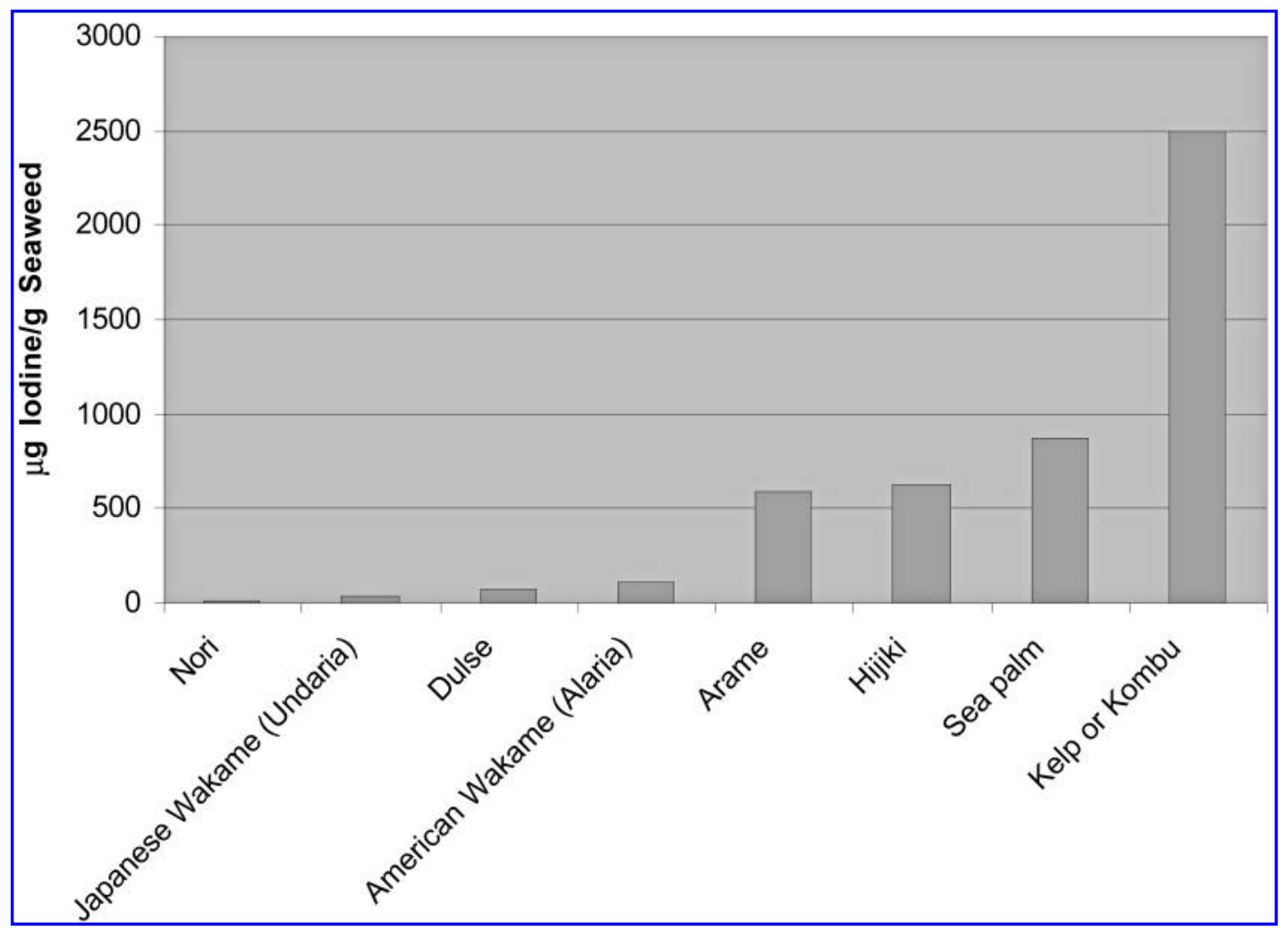

FIG. 2. Comparison of iodine content of common dietary seaweeds. 


\section{Encapsulation}

The seaweed was shipped by overnight mail to Beehive Botanicals, a subsidiary of Twin Labs (Hayward, WI), where it was tested for mold and fungus and found to be negative. The seaweed was ground and encapsulated into gelatin capsules. No fillers or binders were added to the seaweed powder.

\section{Placebo}

Maltrin M100 maltodextrin (Grain Processing Corp., Muscatine, IA) was used for placebo. The daily dose of 5 $\mathrm{g} /$ day provided $18 \mathrm{kcal}$ of food energy. We used the same capsules for maltodextrin and the seaweed. No fillers or binders were added to the placebo powder.

\section{Iodine content of finished capsules}

Gelatin capsules were used and, when analyzed for iodine content, were found to contain no iodine. The finished seaweed capsules were analyzed, and each capsule contained $47.5 \mu \mathrm{g}$ of iodine. Thus for our study, we provided an additional $475 \mu \mathrm{g}$ of iodine/day.

\section{Soy protein}

Soy powder [Supro High Protein Nutritious Food Ingredient Powder (with isoflavones)] (lot number G198-8) was provided by Solae Co. (formerly Protein Technologies, Inc., St. Louis, MO). It contained $1.43 \mathrm{mg}$ of total aglycone (unconjugated or free) isoflavone/g of soy powder. We calcu- lated the appropriate dose for each subject based on her weight, so that each woman consumed $2 \mathrm{mg}$ of isoflavones $/ \mathrm{kg}$ of body weight. On average, each woman was given $67.5 \mathrm{~g} /$ day of soy protein. This provided 141.3 $\mathrm{mg}$ /day isoflavones, 376 calories, $2.2 \mathrm{~g}$ of fat, and $22 \mathrm{~g}$ of carbohydrates and supplied $539 \mathrm{~g}$ of calcium. Subjects were advised to consume the soy protein isolate as a substitute meal during the 2 weeks of soy supplementation.

\section{Thyroid hormones}

Chemiluminometric immunoassays (Chiron Diagnostics, East Walpole, MA) were used to measure serum TSH, triiodothyronine (T3), thyroxine (T4), and T3 resin uptake [thyroid hormone-binding ratio (THBR)]. The free T4 index (FTI) was calculated as the product of THBR $\times$ T4. A chemiluminometric enzyme-linked immunosorbent assay was used to measure anti-thyroid peroxidase antibody (ALPCO, American Laboratory Products Co., Wyndham, $\mathrm{NH}$ ) and was sensitive to $5 \mathrm{IU} / \mathrm{mL}$. All of these assays and urinary creatinine were measured by the Endocrine-Hypertension Laboratory at the Brigham \& Women's Hospital, Boston, MA.

\section{Iodine}

Iodine in urine, empty capsules, and finished capsules was analyzed using the ceric-arsenic redox reaction. Samples were analyzed according to standard determination of total iodine protocol as outlined by Benotti et al. ${ }^{23}$ This used the reduction-oxidation reaction between ceric and arsenite cat-

Table 1. Demographic Factors for 25 Women

\begin{tabular}{|c|c|c|c|c|c|}
\hline \multirow[b]{2}{*}{ Characteristic } & \multicolumn{2}{|c|}{ Breast cancer } & \multicolumn{2}{|c|}{ Disease free } & \multirow[b]{2}{*}{$\mathrm{P}$ value } \\
\hline & Number & $\%$ & Number & $\%$ & \\
\hline Education & & & & & $0.58^{\mathrm{a}}$ \\
\hline High school graduate or less & 2 & 20 & 4 & 27 & \\
\hline Some college or associate degree & 4 & 40 & 3 & 20 & \\
\hline Bachelors degree or more & 4 & 40 & 8 & 53 & \\
\hline \multicolumn{6}{|l|}{ Ethnicity } \\
\hline Caucasian American & 10 & 100 & 15 & 100 & - \\
\hline Social status & & & & & $0.36^{\mathrm{a}}$ \\
\hline Living alone & 3 & 30 & 2 & 13 & \\
\hline Living with someone & 7 & 70 & 13 & 87 & \\
\hline Employment & & & & & $0.83^{\mathrm{a}}$ \\
\hline Full-time & 7 & 70 & 9 & 60 & \\
\hline Part-time & 1 & 10 & 1 & 7 & \\
\hline \multirow[t]{2}{*}{ Not working } & 2 & 20 & 5 & 33 & \\
\hline & Mean & $S D$ & Mean & $S D$ & \\
\hline Age (years) & 58.4 & 6.1 & 58.1 & 8.5 & $0.93^{\mathrm{b}}$ \\
\hline BMI $\left(\mathrm{kg} / \mathrm{m}^{2}\right)$ & 27.2 & 6.7 & 26.2 & 4.4 & $0.66^{\mathrm{b}}$ \\
\hline
\end{tabular}

This analysis includes 25 women, 10 with a history of breast cancer and 15 with no such history.

aBy Fischer's exact test.

by $t$ test. 
alyzed by iodide. The iodine concentration was proportional to its catalytic activity. First, iodine was precipitated with perchloric acid, and the samples were digested with chloric acid. They were then measured spectrometrically at $420 \mathrm{~nm}$
(Autoanalyzer, Technicon Instrument, Inc., Tarrytown, NY). Calculations were based on an iodine standard curve. The urine results were calculated as $\mu \mathrm{g}$ of iodine/dL, per $\mathrm{g}$ of creatinine, or total urinary iodine/day.

Table 2. Life-Style- and Health-Related Factors for 25 Women

\begin{tabular}{|c|c|c|c|c|c|}
\hline \multirow[b]{2}{*}{ Characteristic } & \multicolumn{2}{|c|}{ Breast cancer } & \multicolumn{2}{|c|}{ Disease free } & \multirow[b]{2}{*}{$\mathrm{P}$ value } \\
\hline & Number & $\%$ & Number & $\%$ & \\
\hline \multicolumn{5}{|l|}{ General health } & \multirow[t]{4}{*}{$0.72^{\mathrm{a}}$} \\
\hline Excellent & 2 & 20 & 5 & 33 & \\
\hline Very good & 6 & 60 & 9 & 60 & \\
\hline Good & 2 & 20 & 1 & 7 & \\
\hline \multicolumn{5}{|l|}{ Exercise } & \multirow{3}{*}{$0.12^{\mathrm{a}}$} \\
\hline Yes & 5 & 50 & 12 & 80 & \\
\hline No & 5 & 50 & 3 & 20 & \\
\hline \multicolumn{5}{|l|}{ Alcohol use ${ }^{\mathrm{b}}$} & \multirow[t]{3}{*}{$0.67^{\mathrm{a}}$} \\
\hline Yes & 4 & 40 & 4 & 27 & \\
\hline No & 6 & 60 & 11 & 73 & \\
\hline \multicolumn{5}{|l|}{ Multivitamin use } & \multirow[t]{3}{*}{$0.69^{\mathrm{a}}$} \\
\hline Yes & 6 & 60 & 7 & 47 & \\
\hline No & 4 & 40 & 8 & 53 & \\
\hline \multicolumn{5}{|l|}{ Herbal supplements use } & \multirow[t]{3}{*}{$1.00^{\mathrm{a}}$} \\
\hline Yes & 4 & 40 & 7 & 47 & \\
\hline No & 6 & 60 & 8 & 53 & \\
\hline \multicolumn{5}{|l|}{ Hysterectomy } & \multirow[t]{3}{*}{$0.27^{\mathrm{a}}$} \\
\hline Yes & 3 & 30 & 1 & 7 & \\
\hline No & 7 & 70 & 14 & 93 & \\
\hline \multicolumn{5}{|l|}{ Ever pregnant } & \multirow[t]{3}{*}{$1.00^{\mathrm{a}}$} \\
\hline Yes & 9 & 90 & 13 & 87 & \\
\hline No & 1 & 10 & 2 & 13 & \\
\hline \multicolumn{5}{|l|}{ Menopausal symptoms } & \multirow[t]{3}{*}{$0.24^{\mathrm{a}}$} \\
\hline Yes & 6 & 60 & 5 & 33 & \\
\hline No & 4 & 40 & 10 & 67 & \\
\hline \multicolumn{5}{|l|}{ Self-medication for menopausal symptoms ${ }^{c}$} & \multirow[t]{3}{*}{$1.00^{\mathrm{a}}$} \\
\hline Yes & 3 & 30 & 5 & 33 & \\
\hline No & 7 & 70 & 10 & 67 & \\
\hline \multicolumn{6}{|l|}{ Family history of breast cancer } \\
\hline Yes & 2 & 20 & 10 & 67 & $0.04^{\mathrm{a}}$ \\
\hline No & 8 & 80 & 5 & 33 & \\
\hline If yes, first-degree breast cancer & & & & & $0.45^{\mathrm{a}}$ \\
\hline Not applicable & 8 & - & 5 & - & \\
\hline Yes & 1 & 50 & 8 & 80 & \\
\hline No & 1 & 50 & 2 & 20 & \\
\hline If first-degree, breast cancer type & & & & & $1.00^{\mathrm{a}}$ \\
\hline Premenopausal & 0 & 0 & 1 & 13 & \\
\hline Postmenopausal & 1 & 100 & 7 & 87 & \\
\hline Not applicable & 8 & - & 5 & - & \\
\hline Missing & 1 & - & 2 & - & \\
\hline & Mean & $S D$ & Mean & $S D$ & \\
\hline Age at first pregnancy & 24.2 & 3.4 & 24.3 & 3.7 & $0.24^{\mathrm{d}}$ \\
\hline Age (years) at menopause & 48.8 & 3.5 & 50.5 & 2.2 & $0.15^{\mathrm{d}}$ \\
\hline Social support $\mathrm{e}^{\mathrm{e}}$ & 17.9 & 9.9 & 13.1 & 9.4 & $0.24^{\mathrm{d}}$ \\
\hline Number of miscarriages & 0.9 & 1.4 & 0.4 & 0.8 & $0.28^{\mathrm{d}}$ \\
\hline
\end{tabular}

This analysis includes 25 women, 10 with a history of breast cancer and 15 with no such history.

aBy Fischer's exact test.

${ }^{b}$ One or fewer drinks per week.

'Self-medication of menopausal symptoms with dietary herbal supplements, or over-the-counter drugs.

dBy $t$ test.

eSocial support was defined as the number of friends and relatives a woman was in contact with during a week. 


\section{Urine collection}

Women collected 48-hour urine specimens in 3-L containers to which $3 \mathrm{~g}$ of ascorbic acid powder had been added. Women stored the collection jugs in their refrigerators until they came in for their next clinic visit (within a day of the end of the collection period). After the contents of the jugs were completely mixed, aliquots were taken and stored at $-20^{\circ} \mathrm{C}$ until analysis.

\section{Statistical analyses}

Analyses were conducted on 25 women using an intention-to-treat approach. The study sample characteristics are presented using descriptive statistics. To test the main study hypotheses, a repeated-measures analysis of variance was conducted using Proc Mixed in SAS (SAS, Cary, NC). ${ }^{24}$ In these models, subject was fit as the repeated factor, while the independent variables treatment group (placebo, seaweed, soy, and seaweed plus soy), treatment arm (treatment followed by placebo or placebo followed by treatment), and disease status (history of breast cancer: yes or no) were fit as independent variables. Individual models were run for seven dependent variables: serum total T3, T4, FTI, TSH, and urinary iodine (24-hour excretion, concentration/dL, and iodine standardized per $\mathrm{g}$ of creatinine). Results are presented as both average concentrations $( \pm S D)$ and least squares means, and the differences are tested using the pdiff option of the Proc Mixed procedure.

\section{RESULTS}

The demographic and life-style characteristics of the 25 subjects are presented in Tables 1 and 2. The only significant difference between the women who had been treated for breast cancer and those who had never had breast cancer was in family history. Although we had expected that women with breast cancer would have a stronger family history of breast cancer, that was not the case in our study. Two-thirds of the control women had a family history of breast cancer compared to only $20 \%$ of the breast cancer patients $(P<.04)$, although there was no difference between groups in number of first-degree relatives who had been diagnosed with breast cancer.

There were no differences in thyroid function during seaweed and/or soy ingestion between the women who had been treated for early breast cancer but were disease free compared to women who never had breast cancer.

Table 3 presents average serum measurements of thyroid function and urinary iodine excretion in each treatment group. The only significant effects were that seaweed markedly increased urinary iodine excretion and slightly increased serum TSH (Table 3 and Fig. 3). These seaweed effects were not altered by soy ingestion.

Because the within-subject variation in 24-hour urinary creatinine excretion averaged $15 \%$ (median 13\%), we were concerned that urine collections may have been incomplete for some subjects. Data were analyzed using urinary iodine/g of creatinine concentration, urinary iodine concentration $(\mu \mathrm{g} / \mathrm{dL})$, and total 24-hour urinary iodine (I/day) excretion. The statistical results did not vary, suggesting that our ability to estimate treatment effects was not affected by this factor. Soy protein isolate supplementation had no significant effect, and there was no evidence that there was an interaction between seaweed and soy, when administered together.

Body mass index (BMI) of the women varied from 18 to $44 \mathrm{~kg} / \mathrm{m}^{2}$. We found no treatment-by-BMI interaction, and although there was a marginally significant association between weight and TSH, there was no evidence that it influenced our estimation of the seaweed effect.

\section{DISCUSSION}

Our data support our first hypothesis that seaweed contains bioavailable iodine, and that consuming seaweed supplements would affect thyroid function. The changes were small, and although statistically significant for an increase in serum TSH, the values remained well within normal ranges and were unlikely to be physiologically important.

Table 3. Mean Values for Thyroid Function and Urinary Iodine Excretion by Treatment Period for 25 Women

\begin{tabular}{|c|c|c|c|c|c|c|c|c|}
\hline \multirow[b]{2}{*}{ Thyroid tests } & \multicolumn{2}{|c|}{ Placebo } & \multicolumn{2}{|c|}{ Seaweed } & \multicolumn{2}{|c|}{ Soy } & \multicolumn{2}{|c|}{ Seaweed and soy } \\
\hline & Mean & $S D$ & Mean & $S D$ & Mean & $S D$ & Mean & $S D$ \\
\hline \multicolumn{9}{|l|}{ Serum hormones } \\
\hline T3 (ng/dL) & 124.1 & 16.5 & 128.4 & 16.2 & 125.6 & 17.7 & 125.8 & 16.6 \\
\hline $\mathrm{T} 4(\mu \mathrm{g} / \mathrm{dL})$ & 6.6 & 1.0 & 6.6 & 0.9 & 6.8 & 1.1 & 6.7 & 0.8 \\
\hline FTI & 5.7 & 0.7 & 5.8 & 0.7 & 5.9 & 0.9 & 5.9 & 0.7 \\
\hline $\mathrm{TSH}(\mu \mathrm{IU} / \mathrm{mL})$ & 1.69 & 0.95 & $2.19^{* *}$ & 1.23 & 1.64 & 1.01 & $1.94^{* *}$ & 1.13 \\
\hline \multicolumn{9}{|l|}{ Urinary iodine excretion } \\
\hline Iodine ( $\mu \mathrm{g} /$ day) & 265.8 & 155.8 & $567.8^{* *}$ & 177.8 & 290.5 & 190.9 & $545.6^{* *}$ & 136.7 \\
\hline Iodine ( $\mu \mathrm{g} / \mathrm{g}$ of creatinine) & 290.5 & 147.8 & $586.9^{* *}$ & 177.6 & 328.5 & 185.4 & 571.7 & 147.8 \\
\hline Iodine $(\mu \mathrm{g} / \mathrm{dL})$ & 13.5 & 7.8 & $31.5^{* *}$ & 12.3 & 115.0 & 12.2 & 28.7 & 8.2 \\
\hline
\end{tabular}

This analysis includes 25 women, 10 with a history of breast cancer and 15 with no such history. As this was a crossover study, each woman received each treatment, and these values represent the average values in all 25 subjects.

${ }^{* *} P<.01$ versus placebo or soy alone. 
A

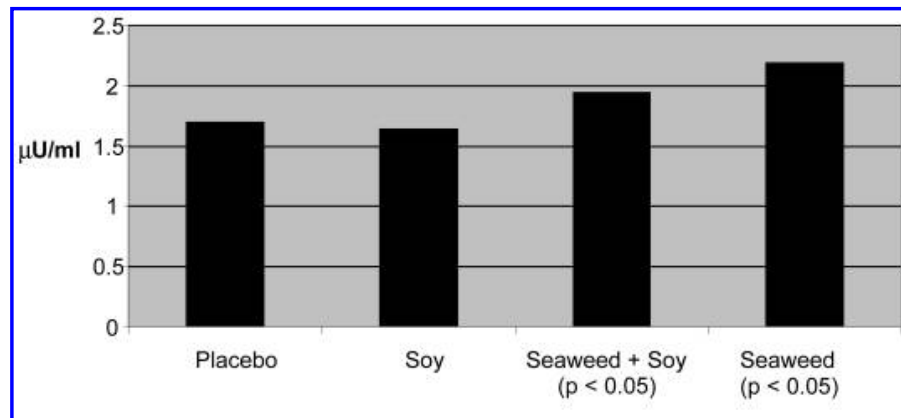

B

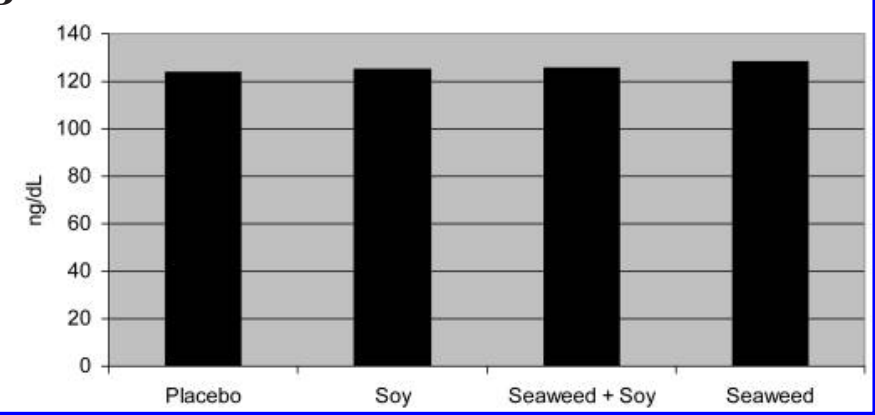

C

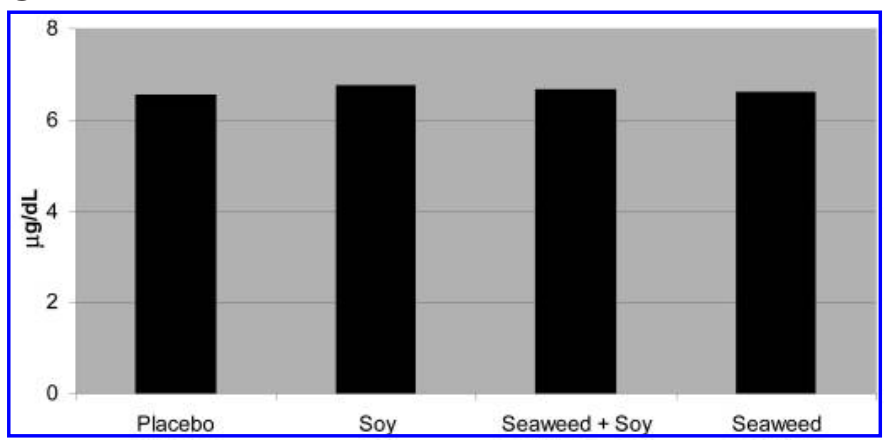

FIG. 3. Comparison of treatment effects on the thyroid hormones TSH (A), T3 (B), and T4 (C).

However, some common dietary seaweeds, especially kelp (Laminaria), can contain 40 times as much iodine. The small changes we observed in euthyroid women may not be representative of the effects of high-iodine kelp in the general population.

Soy protein isolate supplementation has been associated with goiter formation in iodine-deficient rats and humans. ${ }^{17,25}$ This does not appear to be the case in healthy postmenopausal American women. In our study of iodinereplete subjects, none of the women experienced clinically significant changes in thyroid hormones or urinary excretion of iodine during either of the two 1-week periods of high isoflavone (average $141 \mathrm{mg}$ of total isoflavones/day) soy powder supplementation. Our adjusted dose of isoflavones to body weight ( $2 \mathrm{mg}$ of isoflavones $/ \mathrm{kg} / \mathrm{day}$ ), resulted in an average daily intake of $67.5 \mathrm{~g}$ of soy protein, or about six to seven times the daily intake of soy protein in Japan. ${ }^{26}$ The previous study by Bruce et al. ${ }^{27}$ of 38 healthy postmenopausal women in a randomized double-blind placebo-controlled study showed no effect of soy supplementation on thyroid function in women given slightly less (90 mg of total isoflavones/day) soy protein isolate and followed for 6 months. Likewise, two other studies have investigated the longer-term effects of soy protein isolate on thyroid function. Duncan et al. ${ }^{28}$ followed 18 postmenopausal women given the same dose of soy protein isolate supplement ( $2 \mathrm{mg}$ of isoflavones $/ \mathrm{kg} /$ day) for 3 months and found no change in thyroid hormone concentrations. In contrast, Persky et al. ${ }^{29}$ studied 46 postmenopausal women who consumed either a high ( $90 \mathrm{mg} /$ day) isoflavone soy protein isolate (ISP 90, Protein Technologies) or moderate (56 $\mathrm{mg} / \mathrm{day}$ ) isoflavone (ISP56, Protein Technologies) for 6 months and reported small but statistically significant changes in thyroid function. In these women, serum TSH was significantly higher at 3 and 6 months in women ingesting ISP90, serum T4 was significantly higher in women ingesting ISP56 at both 3 and 6 months, and serum T3 was significantly higher at 6 months in the women ingesting ISP90. However, it is difficult to interpret these findings since the hormone values for the women in the three groups (control, ISP56, and ISP90) differed at baseline. All values remained the within normal ranges. Our results from two separate 1-week exposures to high soy protein isolate provide additional support for the hypothesis that soy supplementation in iodine-replete populations have minimal or no effects on thyroid function.

On average, the women in our study excreted $266 \mu \mathrm{g}$ of $\mathrm{I} / \mathrm{day}(13 \mu \mathrm{g} / \mathrm{dL})$ during the control period and $587 \mu \mathrm{g}$ of $\mathrm{I} /$ day $(32 \mu \mathrm{g} / \mathrm{dL})$ while ingesting seaweed. Thus, our subjects were iodine sufficient at the beginning of the study and slightly above average for the United States. ${ }^{30}$ Exposure to dietary iodine in Asia is much higher. For example, in Japan, the mean urinary iodine excretion in apparently healthy men and women in Sapporo was 5,100 $\mu \mathrm{g} /$ day $(n=4,138)^{31}$ and $211 \mu \mathrm{g} / \mathrm{dL}$ in Korea $(n=207),{ }^{32}$ compared to a median of approximately $217 \mu \mathrm{g}$ /day in 20,369 Americans. ${ }^{30}$ When urinary iodine is standardized for creatinine content, the women in our study excreted $291 \mu \mathrm{g} / \mathrm{g}$ when ingesting placebo and $587 \mu \mathrm{g} / \mathrm{g}$ when ingesting seaweed. This is close to $673 \mu \mathrm{g} / \mathrm{g}$ of creatinine reported for 278 healthy adults in Korea, ${ }^{33}$ where seaweed intake is common, and suggests that our study used seaweed exposure that approximates that found in Asia, where a variety of different kinds of seaweeds are eaten daily in small amounts.

There have been two other studies confirming the bioavailability of iodine from seaweed. Clark et al. ${ }^{34}$ conducted a similar double-blind prospective 6-week clinical trial in 36 healthy euthyroid subjects. The study utilized commercial kelp tablets with an estimated $250 \mu \mathrm{g}$ per capsule iodine content. Alfalfa (four capsules per day) was compared with high-dose kelp (four capsules per day) and lowdose kelp (two kelp capsules per day and two alfalfa capsules per day). Similar to our study, TSH increased significantly 
in both kelp-supplemented groups. Serum free T4 concentrations did not change with either kelp supplementation, but total T3 did significantly after high-dose kelp; the latter finding remains unexplained. Their low-dose kelp ingestion corresponded to that in the present study, and urine iodine excretion was similar. Unlike our study in which we observed a slight but nonsignificant increase in $\mathrm{T} 3$, in the study by Clark et al., ${ }^{34} \mathrm{~T} 3$ decreased significantly after high-dose kelp therapy.

In the second study of iodine bioavailability from seaweed, Aquaron et al. ${ }^{35}$ reported on the 48 -hour short-term effect of dietary seaweed in two different geographic locations. In 18 healthy iodine-replete volunteers in Marseille, France, $90 \%$ of the seaweed iodine was excreted, but in a mildly iodine-deficient population in Brussels, Belgium, only $62 \%$ of the seaweed iodine was excreted in 48 hours. In our study in an iodine-sufficient population, $60 \%$ of the seaweed iodine was excreted in the urine. It is unclear why this was the case. When we compared within-subject variation in total urinary creatinine content of the collection specimens, the coefficient of variation averaged $15 \pm 7 \%$, with a range between $4 \%$ and $30 \%$. We hypothesize that some of the urine collections for some women at a few time points may have been incomplete, possibly explaining the lower percentage of excreted iodine observed in our iodinereplete population.

In Japan and Korea, exposure to high iodine-containing foods usually begins in utero and via breast milk. ${ }^{36}$ A study of 50 lactating Korean mothers reported the average maternal iodine intake immediately postpartum was $2,744 \mu \mathrm{g} /$ day, decreasing to $1,295 \mu \mathrm{g} / \mathrm{day}$ at 4 weeks. The iodine concentration of the colostrum was $2,170 \mu \mathrm{g} / \mathrm{L}$, and breast milk at 4 weeks contained $892 \mu \mathrm{g} / \mathrm{L}$. This supports the possibility that early exposure to high iodine may be important in the habituation of people living in Asia to high ambient levels of dietary iodine.

Even though we report a small rise in serum TSH with moderate seaweed iodine exposure, thyroid disease in Japan is less common than in the United States. The prevalence of hyperthyroidism (TSH $<0.15 \mu \mathrm{U} / \mathrm{L}$ ) among 4,110 people living on Hokkaido in Japan was $0.6 \%$ among people living in the capitol of Sapporo and 1.1\% among people living along the coast, with the latter presumably having more seaweed in their diets. ${ }^{31}$ By comparison, the prevalence of hyperthyroidism (TSH $<0.1 \mu \mathrm{U} / \mathrm{L}$ ) among 13,344 adults with no underlying thyroid problems in the United States was $1.3 \% .{ }^{37} \mathrm{~A}$ slightly more stringent definition of hyperthyroidism in the United States $(<0.1 \mu \mathrm{U} / \mathrm{L})$ than in Japan $(<0.15 \mu \mathrm{U} / \mathrm{L})$ may partially explain the minor differences in rates between the two countries. Hypothyroidism (TSH $>5.0 \mu \mathrm{U} / \mathrm{L}$ ) prevalence in Japan was $1.3 \%$ in Sapporo and $3.8 \%$ along the coast. ${ }^{31}$ The U.S. prevalence of hypothyroidism (TSH $>4.5 \mu \mathrm{U} / \mathrm{L}$ ) was $4.6 \% .{ }^{37}$ Again, the slightly different cutoff points may explain the greater prevalence in the United States. Age-standardized incidence of thyroid cancer rates are higher in the United States $(6.2 / 100,000)$ compared to Japan $(4.8 / 100,000)$, but the death rates from thyroid cancer are twice as high in Japan (0.6) as in the United States (0.3). ${ }^{19}$ Using autopsy studies to estimate the rate of undetected thyroid cancer at death, the prevalence in Japan was $35 \%,{ }^{38}$ compared to $3.6 \%$ in the United States. ${ }^{39}$ This high prevalence of occult thyroid tumors (35\%) but uncommon clinical diagnosis (4.8 age-standardized rate) and mortality (0.6 age-standardized rate) in Japan suggests that factors such as diet or environment play a role in thyroid cancer initiation and progression. People who immigrate from Japan to the United States have higher rates of many cancers, including thyroid cancer. ${ }^{40}$

The safety of high seaweed iodine supplements in the United States, where people have not been exposed since infancy, may be different than it is in Japan. Based on reviews of thyroid status of people in the United States, between $9.5 \%$ to $24 \%$ of women older than 60 years of age had evidence of thyroid dysfunction (TSH $>5 \mathrm{mIU} / \mathrm{L}){ }^{37,41}$ Even among people known to have hypothyroidism, a recent study found that $40 \%$ of people who were taking thyroid medications had elevated or suppressed serum TSH levels, ${ }^{41}$ suggesting poor patient compliance, inadequate supervision, or variability in $\mathrm{T} 4$ content of the prescribed tablets. These baseline characteristics of U.S. populations suggest that low iodine-containing seaweeds would be safe, but the more typical high iodine seaweeds (kelp) deserve further study. Since older women have a high prevalence of Hashimoto's thyroiditis, which predisposes them to iodineinduced hypothyroidism, or nodular goiter, predisposing them to iodine-induced hyperthyroidism, careful monitoring of thyroid function is advisable in iodine-exposed women with positive thyroid antibodies or nodular goiter. ${ }^{42}$

With any dietary change there is the question of possible harm. In addition to thyroid function, long-term exposure to seaweed and thyroid cancer risk need to be considered. Reports of an association between thyroid disease and breast cancer have been found in some, but not all, epidemiologic studies. ${ }^{43}$ In the largest case control study including 9,257 American women (4,575 cases and 4,682 controls), the only significant association between thyroid disease and breast cancer was that parous women who had been treated for thyroid cancer had an increased risk of breast cancer. ${ }^{44}$ Likewise, a large retrospective study of 41,686 breast cancer patients and 3,662 thyroid cancer patients seen at MD Anderson Hospital reported a significantly increased risk of developing breast cancer after thyroid cancer in young women. ${ }^{45}$ This finding was explored further using the National Cancer Institute's Surveillance, Epidemiology and End Results database with 1,333,115 person-years of data. Women who were diagnosed with thyroid cancer had a significantly increased risk of developing breast cancer. Again, those who had been treated for thyroid cancer had an increased risk of breast cancer (relative risk 1.18, $P=.007$ ). The effect was most pronounced in premenopausal women (relative risk 1.42, $P=.001) .{ }^{46} \mathrm{It}$ is possible that therapy of thyroid cancer with large doses of ${ }^{121}$ I may play a role in this association since the nonlactating breast weakly concentrates iodine. 
In a more general sense, the role of iodine, as opposed to thyroid function, may be important, as there is some suggestion that iodine deficiency is a risk factor for breast cancer. ${ }^{4-49}$ Iodine is critical for the health of newborn infants, and during lactation and in rapidly dividing breast cancer cells. These observations led to the identification of the mammary gland iodide transporter (sodium iodide symporter) protein, ${ }^{50}$ important in breast cell differentiation during breast development. Additionally, therapeutic success using oral iodine for breast fibrocystic disease has been reported. ${ }^{51,52}$ Venuri $^{47}$ hypothesized that iodine is a primitive antioxidant that has been evolutionarily conserved, and provides protection to cell membranes. The form of iodine may be particularly important for breast cancer. Aceves et al. ${ }^{53}$ have reviewed the literature of known effects of iodine on breast cancer and concluded that in its oxidative form, it is a potent antioxidant, inducing antiproliferative and apoptotic actions via iodinated lipids called iodolactones. Potassium iodine, as used in iodine supplementation programs, does not have these effects. The in vivo data are also suggestive of a role for seaweed iodine in mammary tissue protection. Three studies by Funahashi and coworkers explored the relationship of iodine and iodine in seaweed as factors in inhibition of 7,12-dimethylbenz[ $a$ ]anthracene-induced mammary tumors in rats. ${ }^{54-56}$ As a possible mechanism, they reported a high correlation between serum iodine and apoptosis of mammary cancer cells. These results, along with those we $\mathrm{e}^{57}$ and others ${ }^{58-60}$ have reported for dietary seaweed as inhibitory of 7,12-dimethylbenz [ $a$ ]anthracene-induced mammary tumors, are supportive of the idea that seaweed, possibly via iodine, could be involved in breast cancer prevention.

\section{CONCLUSION}

In an iodine-replete population of healthy postmenopausal women with normal thyroid function, the ingestion of an additional $475 \mu \mathrm{g}$ of I/day was associated with a small but significant increase in serum TSH. Soy protein isolate had no effect on thyroid function or iodine excretion. A history of treatment for early breast cancer (Stage I or II) did not alter the changes observed in the seaweed-associated increase in TSH or iodine excretion. However, our sample size was small, and all women in the present study were screened to rule out underlying thyroid disease. It is unknown how seaweed ingestion might affect women with underlying thyroid disease. Given appropriate medical supervision and prior screening for allergies to iodine and thyroid function, consumption of low iodine seaweed and soy protein isolate is unlikely to cause serious side effects.

\section{ACKNOWLEDGMENTS}

We would like to thank Larch Hanson and Shep Erhart for their assistance in identifying and collecting the seaweed. In addition, Drs. Katherine Edmiston, Michael Wertheimer, and Mary Costanza were helpful in com- ments on study design and patient recruitment. Sue Druker and Cara Ebbeling provided excellent project coordination. Dr. Judy Ockene was gracious in mentoring this project. Support for this study was provided by the Susan G. Komen Breast Cancer Foundation (Grant 9735) and the U.S. Army Medical Research and Materiel Command under DAMD 17-98-1-8207.

\section{REFERENCES}

1. Hebert JR, Hurley TG, Olendzki B, Ma Y, Teas J, Hampl JS: Nutritional and socioeconomic factors in relation to prostate cancer mortality: a cross-national study. J Natl Cancer Inst 1998;90: 1637-1647.

2. Hebert JR, Rosen A: Nutritional, socioeconomic, and reproductive factors in relation to female breast cancer mortality: findings from a cross-national study. Cancer Detect Prev 1996;20: 234-244.

3. Kodama M, Kodama T, Miura S, Yoshida M: Nutrition and breast cancer risk in Japan. Anticancer Res 1991;11:745-754.

4. Reddy BS, Cohen LA, McCoy GD, Hill P, Weisburger JH, Wynder EL: Nutrition and its relationship to cancer. Adv Cancer Res 1980;32:237-345.

5. Morrison AS, Black MM, Lowe CR, MacMahon B, Yuasa S: Some international differences in histology and survival in breast cancer. Int J Cancer 1973;11:261-267.

6. Ohsumi S, Sakamoto G, Takashima S, et al.: Long-term results of breast-conserving treatment for early-stage breast cancer in Japanese women from multicenter investigation. $\mathrm{Jpn} \mathrm{J}$ Clin Oncol 2003;33:61-67.

7. Yamamoto S, Sobue T, Kobayashi M, Sasaki S, Tsugane S, Japan Public Health Center-Based Prospective Study on Cancer Cardiovascular Diseases Group: Soy, isoflavones, and breast cancer risk in Japan. J Natl Cancer Inst 2003;95:906-913.

8. Fujimaki S, Hayashi K: Re: Soy, isoflavones, and breast cancer risk in Japan. J Natl Cancer Inst 2003;95:1881-1882.

9. Key TJ, Sharp GB, Appleby PN, Beral V, Goodman MT: Soya foods and breast cancer risk: a prospective study in Hiroshima and Nagasaki, Japan. Br J Cancer 1999;81:1248-1256.

10. Teas J, Pino S, Critchley A, Braverman LE: Variability of iodine content in common commercially available edible seaweeds. Thyroid 2004;14:836-841.

11. Paul T, Meyers B, Witorsch RJ, et al:: The effect of small increases in dietary iodine on thyroid function in euthyroid subjects. Metabolism 1988;37:121-124.

12. Thomson CD: Dietary recommendations for iodine around the world. IDD Newsletter 2002;18:38-42.

13. Arasaki S, Arasaki T: Vegetables from the Sea, Japan Publications Inc., Tokyo, 1983.

14. Toyokawa H: Nutritional status in Japan from the viewpoint of numerical ecology. Social Sci Med 1978;12:517-524.

15. Matsuzaki S, Iwamura K: Application of seaweeds to human nutrition and medicine. In: Nahrung aus dem Meer [Food from the $\mathrm{Sea}$ ] (von Horst Noelle H, ed.), Springer-Verlag, New York, 1981, pp.162-184.

16. Fisheries Information Newsletter 95 SotPC. Seaweed's Nutritional Value. 2000. http://www.spc.int/coastfish/News/Fish_ News/95/NIAR_9.htm (accessed March 2, 2004). 
17. Doerge DR, Sheehan DM: Goitrogenic and estrogenic activity of soy isoflavones. Environ Health Perspect 2002;110:349-353.

18. Messina M, Gardner C, Barnes S: Gaining insight into the health effects of soy but a long way still to go: commentary on the fourth International Symposium on the Role of Soy in Preventing and Treating Chronic Disease. J Nutr 2002;132 (Suppl):547S-551S.

19. Ferlay J, Bray F, Pisani P, Parkin DM: Cancer Incidence, Mortality and Prevalence Worldwide. GLOBOCAN 2000 Version 1.0, IARC Press, Lyon, France, 2001.

20. Marqusee E, Braverman LE, Lawrence JE, Carroll JS, Seely EW: The effect of droloxifene and estrogen on thyroid function in postmenopausal women. $J$ Clin Endocrinol Metab 2000;85: 4407-4410.

21. Zidan J, Rubenstein W: Effect of adjuvant tamoxifen therapy on thyroid function in postmenopausal women with breast cancer. Oncology 1999;56:43-45.

22. Anker GB, Lonning PE, Aakvaag A, Lien EA: Thyroid function in postmenopausal breast cancer patients treated with tamoxifen. Scand J Clin Lab Invest 1998;58:103-107.

23. Benotti J, Benotti N, Pino S, Gardyna H: Determination of total iodine in urine, stool, diets, and tissue. Clin Chem 1965;11: 932-936.

24. SAS: SAS/STAT Software: Changes and Enhancements Through Release 8.01(Guide), SAS Institute Inc., Cary, NC, 2003.

25. Ikeda J, Kawamoto N, Mori H, Murakami T: A system of health education using dietary assessment. Nippon Koshu Eisei Zasshi 2001;48:28-37.

26. Messina M, Messina V: Provisional recommended soy protein and isoflavone intakes for healthy adults: rationale. Nutr Today 2003;38:100-109.

27. Bruce B, Messina M, Spiller GA: Isoflavone supplements do not affect thyroid function in iodine-replete postmenopausal women. J Med Food 2003;6:309-316.

28. Duncan AM, Underhill KE, Xu X, Lavalleur J, Phipps WR, Kurzer MS: Modest hormonal effects of soy isoflavones in postmenopausal women. J Clin Endocrinol Metab 1999;84: 3479-3484.

29. Persky VW, Turyk ME, Wang L, et al.: Effect of soy protein on endogenous hormones in postmenopausal women. Am J Clin Nutr 2002;75:145-153.

30. Hollowell JG, Staehling NW, Hannon WH, et al.: Iodine nutrition in the United States. Trends and public health implications: iodine excretion data from National Health and Nutrition Examination Surveys I and III (1971-1974 and 1988-1994). J Clin Endocrinol Metab 1998;83:3401-3408.

31. Konno N, Iizuka N, Kawasaki K, et al.: Screening for thyroid dysfunction in adults residing in Hokkaido Japan: in relation to urinary iodide concentration and thyroid autoantibodies. Hokkaido Igaku Zasshi 1994;69:614-626.

32. Kim JY, Kim KR: Dietary iodine intake and urinary iodine excretion in patients with thyroid diseases. Yonsei Med J 2000; 41:22-28.

33. Kim JY, Moon SJ, Kim KR, Sohn CY, Oh JJ: Dietary iodine intake and urinary iodine excretion in normal Korean adults. Yonsei Med J 1998;39:355-362.

34. Clark CD, Bassett B, Burge MR: Effects of kelp supplementation on thyroid function in euthyroid subjects. Endocr Pract 2003; 9:363-369.
35. Aquaron R, Delange F, Marchal P, Lognone V, Ninane L: Bioavailability of seaweed iodine in human beings. Cell Mol Biol 2002;48:563-569.

36. Moon S, Kim J: Iodine content of human milk and dietary iodine intake of Korean lactating mothers. Int J Food Sci Nutr 1999;50:165-171.

37. Hollowell JG, Staehling NW, Flanders WD, et al:: Serum TSH, $\mathrm{T}(4)$, and thyroid antibodies in the United States population (1988 to 1994): National Health and Nutrition Examination Survey (NHANES III). J Clin Endocrinol Metab 2002;87:489-499.

38. Miller BA, Ries LAG, Ries BF, et al.: SEER Cancer Statistics Review, 1973-1990, NIH Publication 93-2789, National Cancer Institute, Bethesda, MD, 1993.

39. Wang C, Crapo LM: The epidemiology of thyroid disease and implications for screening. Endocrinol Metab Clin North Am 1997;26:189-218.

40. Tominaga S: Cancer incidence in Japanese in Japan, Hawaii, and western United States. Natl Cancer Inst Monogr 1985;69:83-92.

41. Canaris GJ, Manowitz NR, Mayor G, Ridgway EC: The Colorado thyroid disease prevalence study. Arch Intern Med 2000;160: 526-534.

42. Roti E, Colzani R, Braverman LE: Adverse effects of iodine on the thyroid. Endocrinologist 1997;7:245-254.

43. Turken O, NarIn Y, DemIrbas S, et al.: Breast cancer in association with thyroid disorders. Breast Cancer Res 2003;5: R110-R113.

44. Simon MS, Tang MT, Bernstein L, et al.: Do thyroid disorders increase the risk of breast cancer? Cancer Epidemiol Biomarkers Prev 2002;11:1574-1578.

45. Vassilopoulou-Sellin R, Palmer L, Taylor S, Cooksley CS: Incidence of breast carcinoma in women with thyroid carcinoma. $\underline{\mathrm{Can}-}$ cer 1999;85:696-705.

46. Chen AY, Levy L, Goepfert H, Brown BW, Spitz MR, Vassilopoulou-Sellin R: The development of breast carcinoma in women with thyroid carcinoma. Cancer 2001;92:225-231.

47. Venturi S: Is there a role for iodine in breast diseases? Breast Cancer Res 2001;10:379-382.

48. Smyth PP: Role of iodine in antioxidant defense in thyroid and breast disease. Biofactors 2003;19:121-130.

49. Smyth PP: The thyroid, iodine and breast cancer. Breast Cancer Res 2003;5:235-238.

50. Tazebay UH, Wapnir IL, Levy O, et al.: The mammary gland iodide transporter is expressed during lactation and in breast cancer. Nat Med 2000;6:871-878.

51. Ghent WR, Eskin BA, Low DA, Hill LP: Iodine replacement in fibrocystic disease of the breast. Can J Surg 1993;36:453-460.

52. MacFarlane JK: Elemental iodine: relief for the painful breast? Can J Surg 1993;36:405.

53. Aceves C, Anguiano B, Delgado G: Is iodine a gatekeeper of the integrity of the mammary gland? J Mamm Gland Biol Neoplasia 2005;10:189-196.

54. Funahashi H, Imai T, Tanaka Y, et al.: Suppressive effect of iodine on DMBA-induced breast tumor growth in the rat. $\underline{J \text { Surg }}$ Oncol 1996;61:209-213.

55. Funahashi H, Imai T, Tanaka Y, et al.: Wakame seaweed suppresses the proliferation of 7,12-dimethylbenz(a)-anthracene-induced mammary tumors in rats. Jpn J Cancer Res 1999;90:922-927.

56. Funahashi H, Imai $\mathrm{T}$, Mase $\mathrm{T}$, et al.: Seaweed prevents breast cancer? Jpn J Cancer Res 2001;92:483-487. 
57. Teas J, Harbison ML, Gelman RS: Dietary seaweed (Laminaria) and mammary carcinogenesis in rats. Cancer Res 1984;44: 2758-2761.

58. Yamamoto I, Maruyama H, Moriguchi M: The effect of dietary seaweeds on 7,12-dimethyl-benz[a]anthracene-induced mammary tumorigenesis in rats. Cancer Lett 1987;35:109-118.
59. Maruyama H, Tamauchi H, Hashimoto M, Nakano T: Antitumor activity and immune response of Mekabu fucoidan extracted from sporophyll of Undaria pinnatifida. In Vivo 2003;17:245-249.

60. Takahashi N, Ojika M, Dogasaki C, et al.: Substance isolated from the kelp rhizoid identified as L-tryptophan shows high inhibition of breast cancer. Gan To Kagaku Ryoho 2000;27:251-255. 


\section{This article has been cited by:}

1. J. Teas, M. R. Irhimeh. 2011. Dietary algae and HIV/AIDS: proof of concept clinical data. Journal of Applied Phycology . [CrossRef]

2. Susanne Andres, Klaus Abraham, Klaus Erich Appel, Alfonso Lampen. 2011. Risks and benefits of dietary isoflavones for cancer. Critical Reviews in Toxicology 41:6, 463-506. [CrossRef]

3. Jane Teas, Mohammad R. Irhimeh, Susan Druker, Thomas G. Hurley, James R. Hébert, Todd M. Savarese, Mindy S. Kurzer. 2011. Serum IGF-1 Concentrations Change With Soy and Seaweed Supplements in Healthy Postmenopausal American Women. Nutrition and Cancer 110628105837009. [CrossRef]

4. Jing Li , Xiaochun Teng, Weiwei Wang, Yanyan Chen, Xiaohui Yu, Shen Wang, Jianxin Li, Lin Zhu, Chenyan Li, Chenling Fan, Hong Wang, Hongmei Zhang, Weiping Teng, Zhongyan Shan . 2011. Effects of Dietary Soy Intake on Maternal Thyroid Functions and Serum Anti-Thyroperoxidase Antibody Level During Early Pregnancy. Journal of Medicinal Food 14:5, 543-550. [Abstract] [Full Text HTML] [Full Text PDF] [Full Text PDF with Links]

5. Mark Messina. 2008. Investigating the optimal soy protein and isoflavone intakes for women: a perspective. Women's Health 4:4, 337-356. [CrossRef] 